\title{
Effect of Plastic Surgery Perception and Interest on Appearance Maintenance Behavior and Self-esteem
}

\author{
Sang-Hee Lee ${ }^{1}$ and Yong-Mi Jin ${ }^{2, *}$ \\ ${ }^{1}$ Graduate Student, Dept. of Beauty Arts, Graduate School, Seokyeong University \\ ${ }^{2}$ Professor, Dept. of Hair-Makeup Design, College of Beauty Arts, Seokyeong University
}

\section{미용성형인식 및 관심도가 외모관리행동과 자아존중감에 미치는 영향$$
\text { 이상희 }{ }^{1} \cdot \text { 진용미 }{ }^{2, *}
$$ \\ 1서경대학교 일반대학원 미용예술학과, 대학원생 \\ ${ }^{2}$ 서경대학교 미용예술대학 헤어메이크업디자인학과, 교수}

\begin{abstract}
SPSS 21.0 program was used to analyze data collected from total of 319 surveys on the effect of plastic surgery perception and interest in appearance on appearance orientation and self-esteem. This research aims to identify the impact of plastic surgery perception and interest in appearance on appearance orientation in order to encourage appearance orientation and enhance self-esteem, and the results were the following. Positive factor of plastic surgery perception had negative(-) effect on orientation factor of appearance orientation, and reaction and improvement factors had positive $(+)$ effect on orientation factor. Also, positive factor of plastic surgery perception has negative( $(-)$ effect on self-esteem while improvement factor had positive $(+)$ effect. interest in appearance factor had positive $(+)$ effect on orientation factor of appearance orientation and on self-esteem factor as well. In conclusion, plastic surgery perception can be improved through app review events while 3D virtual surgery and service systems such as happy-call for after service maintenance can increase self-esteem. Methods for increasing interest in appearance include regular exercises and self-makeup classes. Future research could connect plastic surgery perception and interest in appearance with behavior and psychological characteristics to find meaningful connections.
\end{abstract}

Keywords: Appearance orientation, Interest in appearance, Plastic surgery perception, Self-esteem

\section{Introduction}

Rapid modernization and increasing quality of life encourage women to become a much more active participants in society and improved medical technologies caused increased desire for health and beauty among women. Such increased demand for medical procedures go hand in hand with increased interest and demand for plastic surgery. Medical advancements and availability of plastic surgery for general public play their part in expanding plastic surgery activities and appearance orientations. Various plastic surgery researches and interests in modern society produced research outcomes that play

*Corresponding author: Yong-Mi Jin

Tel : +82-2-940-7813

E-mail : 65621107jin@hanmail.net

접수일(2021년 9월 24일)/수정일(2021년 11월 2일)/채택일(2022년 1월 7일) crucial role also in Korea's medical beauty procedures market, hence further promoting the need for research on attitude and behavior intention about plastic surgeries. According to You(2018)'s research on interest and maintenance behavior on appearance depending on prior experience of plastic surgeries indicated people with prior plastic surgery experience were more interested in appearance and showed higher appearance orientation, and such interest and behaviors further demonstrated more interest and positive perception of plastic surgeries. Also, according to research by Lee(2018), interest in appearance was higher among women in their twenties, which suggested then younger women tend to think of good looks as competitive advantage and a form of competence. In Lee(2020)'s research, dissatisfaction with appearance led to psychological problems such as feeling of inferiority and depression, which could lead to serious 
individual self-esteem issues such as self-denial, helplessness and self-depreciation. As such, women are becoming more interested in beauty and are willing to actively express such desire(Huh, 2010). For professional women, appearance is a tool for self-expression which also produces positive impact in interpersonal relationships while increasing sense of satisfaction with oneself, which allow women to be assertive and effective in carrying out tasks, thus making it a resource for gaining competitive edge in society(Kim, 2009). Therefore, this research aims to identify effects of plastic surgery perception and interest on appearance orientation and selfesteem in order to encourage appearance orientation and increase self-esteem.

\section{Theoretical Background}

\section{Plastic Surgery Perception}

Plastic surgery perception is a psychological state which recognizes all plastic surgeries at cosmetic hospitals as not just a means for satisfying psychological desire for beautiful physical appearance but also a way of minimizing internal affliction about one's looks to pursue and enjoy a better life for oneself(Han \& Park, 2008). Research by Hwang et al. (2017) indicated that college students in Korea increasingly though of appearance as important and had lower aversion towards plastic surgery, thus indicating a positive shift of plastic surgery perception and appearance orientation was seen as an essential tool for social success and selfactualization that can influence various aspects of society such as living day to day lives, job prospects and more. Therefore, this research will take into consideration such previous findings and regard appearance orientation as an integral tool for social success and self-actualization to pursue and enjoy a better lifestyle and as a factor which affects various aspects of society.

\section{Interest in Appearance}

Interest in appearance can be defined as the degree of prolonged interest in physical enhancements such as clothes, makeup, accessories, etc. for increasing attractiveness of one's appearance(Chung, 2003). Efforts to work on appearance can be a starting point for freshly assessing and improving oneself and it could also work as a quick visual way to communicate one's identity to others, and beauty standards of the times can have impact on personal lives as well as society's overall objective perception of appearance(Kim, 2014). Hence, interest in appearance is a necessary tool for expressing oneself in different societies, and appearance is an important factor in forming first impression before interpersonal interactions (Yoon, 2007; Kim, 2011). Therefore, this research took such previous research into consideration and selected Yoon(2007)'s research data to see interest in appearance as a form of selfexpression in order to identify impact of interest in appearance on appearance orientation and self-esteem.

\section{Appearance Orientation}

Appearance plays important role on interpersonal relationships and in forming first impressions. Unlike the past where more emphasis was put on abilities when it came to assessing others, in current times there is a perception that attractive appearance can bring social success, thus making people willingly invest in their looks(Hong, 2013). Therefore, appearance orientation is a powerful tool for satisfying one's desire for beauty and expressing one's identity and emotions by presenting one's desired appearance to others in everyday life.

Research by Lim et al.(2018) defined appearance orientation as an adorning behavior to express desired image of oneself to others and it's a way of expressing oneself and one's identity. Various beauty related maintenances such as utilizing clothes, makeup and accessories as well as nails, hairs and body maintenance are also forms of appearance maintenance behavior(Lee \& Jang, 2013). In addition, in order to escape one's physical shortcomings and a sense of inferiority about one's appearance in the rapidly changing beauty standards of society, people continue to engage in appearance orientation(Kaiser, 1990; Kim, 2008).

Therefore, this research takes previous researches into account to consider getting nails, hair and body procedures as a form of appearance orientation to study the impact of plastic surgery perception and interest in appearance on appearance orientation.

\section{Self-Esteem}

The concept of self-esteem was first introduced by American psychologist William James(1890), and it can be defined as a 
self-assessment of one's own attitude about oneself, and it's determined by personal values based on one's ability, value, success, importance etc. that can be a proportional indicator of one's measure of accomplishments(Kim, 2009). Such selfesteem can be formed, changed and developed throughout one's lifespan but some researches indicate that for some people in certain environments, some periods can have negative impact on one's self-esteem(Lee, 2005). Hence, selfesteem means one's own positive or negative assessment of oneself(Choi, 2016).

Therefore, this research will consider previous researches to identify self-esteem as a positive or negative assessment of oneself as part of one's personal value system in order to observe effects of plastic surgery perception and interest in appearance on self-esteem.

\section{Contents and Methods}

\section{Research Tasks and Model}

$<$ Fig. $1>$ is the research model, the research questions according to the purpose of this study are as follows.

First, general properties of research subjects will be analyzed. Second, lower dimension factors of plastic surgery perception, interest in appearance, appearance orientation and

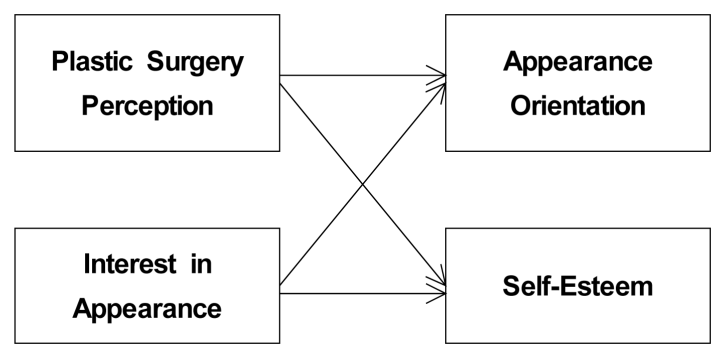

Figure 1. The relationship between cosmetic plastic surgery awareness and interest on appearance management behavior and self-esteem

self-esteem will be extracted. Third, effect of general properties on plastic surgery perception, interest in appearance, appearance orientation and self-esteem will be analyzed. Fourth, effect of plastic surgery perception on appearance orientation will be analyzed. Fifth, effect of plastic surgery perception on selfesteem will be analyzed. Sixth, effect of interest in appearance on appearance orientation will be analyzed. Seventh, effect of interest in appearance on self-esteem will be analyzed.

\section{Research Subject and Data Collection}

For the purpose of this research, self reported surveys were conducted on people living in Seoul and Gyeonggi province. 50 surveys were collected for preliminary research from March $1^{\text {st }} 2021$ until April $1^{\text {st }} 2021$ and survey questions were

Table 1. Composition of Questionnaire

\begin{tabular}{|c|c|c|c|c|}
\hline Survey item & Content & $\begin{array}{l}\text { Number of } \\
\text { Questions }\end{array}$ & Scale & Sources \\
\hline Characteristics & $\begin{array}{l}\text { Gender, age, education level, marriage status, monthly income, occupation, } \\
\text { a source that influences your appearance, skin, makeup, and body care, the } \\
\text { number of times invested in plastic surgery for your appearance, number of } \\
\text { visits to plastic surgery clinics }\end{array}$ & 9 & Name. & Researcher. \\
\hline $\begin{array}{l}\text { Plastic } \\
\text { surgery } \\
\text { perception }\end{array}$ & $\begin{array}{l}\text { Need for cosmetic plastic surgery, changes in appearance, can fill the } \\
\text { deficiencies of body parts, personality changes through cosmetic plastic surgery, } \\
\text { important factors of success, thinking about plastic surgery with friends, } \\
\text { thinking about cosmetic purposes, advertising, brightening, and self-anxiety. }\end{array}$ & 20 & $\begin{array}{l}\text { The } \\
\text { barn. }\end{array}$ & $\begin{array}{l}\text { Oh(2010), Kim(2017), } \\
\text { Lee(2007), } \\
\text { Revised and supplemented. }\end{array}$ \\
\hline $\begin{array}{l}\text { Interest in } \\
\text { appearance }\end{array}$ & $\begin{array}{l}\text { I'm satisfied with my face, I'm interested in media, I like to decorate my } \\
\text { usual appearance, I think time to care about me, I care about how I look to } \\
\text { others, I always care about how I look before going out, I think it's } \\
\text { important to look cool to others. }\end{array}$ & 10 & $\begin{array}{l}\text { The } \\
\text { barn. }\end{array}$ & $\begin{array}{l}\text { Jeong(2009), Boo(2012), } \\
\text { Revised and supplemented. }\end{array}$ \\
\hline $\begin{array}{l}\text { Appearance } \\
\text { orientation }\end{array}$ & $\begin{array}{l}\text { I like how I look in the mirror, my friends like my appearance, other } \\
\text { people's appearance is much better, I want to be thinner, I want to change a } \\
\text { lot of parts of my appearance, I think my height is appropriate, I'm worried } \\
\text { about how I look, I want to be prettier. }\end{array}$ & 10 & $\begin{array}{l}\text { The } \\
\text { barn. }\end{array}$ & $\begin{array}{l}\text { Jeong(2009), Boo(2012), } \\
\text { Revised and supplemented. }\end{array}$ \\
\hline Self-esteem & $\begin{array}{l}\text { I think I'm a valuable person like others, I think I have a lot of good } \\
\text { character, I generally think I'm a failed person, I have nothing to brag } \\
\text { about, I'm as good as most people, I'm satisfied with myself, I wish I could } \\
\text { respect myself more, sometimes I think I'm a useless person }\end{array}$ & 10 & $\begin{array}{l}\text { The } \\
\text { barn. }\end{array}$ & $\begin{array}{l}\text { Jeong(2009), Boo(2012), } \\
\text { Revised and supplemented. }\end{array}$ \\
\hline & Total questions. & & & 51 \\
\hline
\end{tabular}


edited for enhanced clarity of sentence structures and questions. Total of 372 surveys were collected for main research from April $2^{\text {nd }} 2021$ until June 21 $1^{\text {st }} 2021$, and 41 substandard surveys were removed then total of 319 surveys were used as final research data.

\section{Survey Construction}

Survey questions used as measuring tool for this research are shown in $<$ Table $1>$. Survey question prompts used as measuring tools consist of 58 questions on general characteristics, plastic surgery perception, interest in appearance, appearance orientation and self-esteem. All the Likert scales used for this research range from ' 1 : not true at all' to '5: very true' on 5points Likert scale.

\section{Data Processing}

Collected data was put through SPSS 21.0 program to analyze the following.

First, frequency analysis was conducted for the general characteristics of research subjects. Second, factor analysis and reliability analysis were conducted for lower dimension factors of plastic surgery perception, interest in appearance, appearance orientation and self-esteem. Third, t-test and ANOVA analysis were conducted to determine the impact of general properties on plastic surgery perception, interest in appearance, appearance orientation and self-esteem. Forth, multiple regression analysis was conducted for effects of plastic surgery perception on appearance orientation. Fifth, multiple regression analysis was conducted for effects of plastic surgery perception on self-esteem. multiple regression analysis was conducted for effects of interest on appearance orientation. Seventh, multiple regression analysis was conducted for effects of interest in appearance on self-esteem. Principal component analysis was used for factors extraction and Varimax was used for factor rotation. Cronbach's $\alpha$ value was used for reliability analysis for the variables.

\section{Results and Considerations}

\section{General properties of research subjects}

Results of frequency analysis for general properties of research subjects is on $<$ Table $2>$.
Table 2. General Properties

$(\mathrm{N}=250)$

\begin{tabular}{|c|c|c|c|}
\hline & Category & $\begin{array}{l}\text { Frequency } \\
(\mathrm{N})\end{array}$ & $\begin{array}{l}\text { Percentage } \\
(\%)\end{array}$ \\
\hline \multirow{2}{*}{ Gender } & Man & 108 & 33.9 \\
\hline & Woman & 211 & 66.1 \\
\hline \multirow{5}{*}{ Age } & $10 \mathrm{~s}$ & 36 & 11.3 \\
\hline & $20 \mathrm{~s}$ & 188 & 58.9 \\
\hline & $30 \mathrm{~s}$ & 53 & 16.6 \\
\hline & $40 \mathrm{~s}$ & 5 & 1.6 \\
\hline & Over $50 \mathrm{~s}$ & 37 & 11.6 \\
\hline \multirow{4}{*}{$\begin{array}{l}\text { Education } \\
\text { level }\end{array}$} & Below high school & 71 & 22.3 \\
\hline & $\begin{array}{l}\text { Associate degree enrolled/ } \\
\text { graduated }\end{array}$ & 78 & 24.5 \\
\hline & College enrolled/graduated & 145 & 45.5 \\
\hline & Above grad school & 25 & 7.8 \\
\hline \multirow{3}{*}{$\begin{array}{c}\text { Marriage } \\
\text { status }\end{array}$} & Single & 269 & 84.3 \\
\hline & Married & 46 & 14.4 \\
\hline & $\begin{array}{l}\text { Other (divorced, bereaved, } \\
\text { separated, etc.) }\end{array}$ & 4 & 1.3 \\
\hline \multirow{6}{*}{$\begin{array}{l}\text { Monthly } \\
\text { income }\end{array}$} & Less than 1 million won & 120 & 37.6 \\
\hline & Less than 1-2 million won & 67 & 21.0 \\
\hline & Less than 2-3 million won & 59 & 18.5 \\
\hline & Less than 3-4 million won & 21 & 6.6 \\
\hline & Less than 4-5 million won & 6 & 1.9 \\
\hline & More than 5 million won & 46 & 14.4 \\
\hline \multirow{5}{*}{ Occupation } & Student & 127 & 39.8 \\
\hline & Office worker & 110 & 34.5 \\
\hline & Government worker & 3 & 9 \\
\hline & Businessman & 59 & 18.5 \\
\hline & Umemployed & 20 & 6.3 \\
\hline \multirow{9}{*}{$\begin{array}{l}\text { A source that } \\
\text { influences your } \\
\text { appearance, skin, } \\
\text { makeup, and } \\
\text { body care }\end{array}$} & Mother & 21 & 6.6 \\
\hline & Older sister & 22 & 6.9 \\
\hline & Cosmetics salesperson & 6 & 1.9 \\
\hline & Television & 10 & 3.1 \\
\hline & Computer & 57 & 17.9 \\
\hline & $\begin{array}{l}\text { Fashion magazines and } \\
\text { catalogues }\end{array}$ & 23 & 7.2 \\
\hline & Teacher & 2 & .6 \\
\hline & Friend & 106 & 33.2 \\
\hline & etc. & 72 & 22.6 \\
\hline \multirow{4}{*}{$\begin{array}{c}\text { The number of } \\
\text { times invested in } \\
\text { plastic surgery } \\
\text { for your } \\
\text { appearance }\end{array}$} & Never & 214 & 67.1 \\
\hline & Once & 85 & 26.6 \\
\hline & Twice & 18 & 5.6 \\
\hline & More than twice & 2 & .6 \\
\hline \multirow{4}{*}{$\begin{array}{c}\text { Number of visits } \\
\text { to plastic surgery } \\
\text { clinics }\end{array}$} & Never & 224 & 70.2 \\
\hline & Once & 88 & 27.6 \\
\hline & More than twice & 7 & 2.2 \\
\hline & Total & 319 & 100.0 \\
\hline
\end{tabular}


Genders were $66.1 \%$ female and $33.9 \%$ male. For ages, $58.9 \%$ were in $20 \mathrm{~s}, 16.6 \%$ were in $30 \mathrm{~s}, 11.6 \%$ were in $50 \mathrm{~s}$, $11.3 \%$ were in their teens, and $1.6 \%$ were in $40 \mathrm{~s}$, in that order. Level of educations consisted of $45.5 \%$ college enrolled/graduated, $24.5 \%$ associates degree enrolled/graduated, $22.3 \%$ below high school and $7.8 \%$ above grad school. Marriage status ranged from $84.3 \%$ single, $14.4 \%$ married and $1.3 \%$ other (divorced, bereaved, separated, etc.). Monthly income ranged from $37.6 \%$ earning less than 1 million won, $21.0 \%$ earning less than $1-2$ million won, $18.5 \%$ earning less than 2-3 million won, $14.4 \%$ earning more than 5 million won, $6.6 \%$ earning less than 3-4 million won and $1.9 \%$ earning less than 4-5 million won. Professions ranged from $39.8 \%$ students, $34.5 \%$ office workers, $18.5 \%$ businessmen, $6.3 \%$ unemployed to $0.9 \%$ government workers. The sources of information that influence one's appearance, skin, makeup and body ranged from $33.2 \%$ friends, $22.6 \%$ other, $17.9 \%$ computer, $7.2 \%$ fashion magazine and catalogue, $6.9 \%$ older sister, $6.6 \%$ mother, $3.1 \%$ television, $1.9 \%$ cosmetic salesperson to $0.6 \%$ teacher. Number of times invested in plastic surgery for appearance ranged from $67.1 \%$ never, $26.6 \%$ once, $5.6 \%$ twice to $0.6 \%$ more than three times. Visits to plastic surgery clinics ranged from $70.2 \%$ never, $27.6 \%$ once to $2.2 \%$ more than twice.

\section{Lower dimension factors of plastic surgery perception, interest in appearance, appearance orientation, self- esteem}

To measure plastic surgery perception, interest in appearance, appearance orientation and self-esteem, prior to performing factor analysis on 20,10,10 and 9 survey questionnaire, previously measured data was assessed to see if it meets the assumption of factor analysis. Bartlett Sphericity indicated that $\chi^{2}$ is each $1129.107(\mathrm{df}=28$, Sig. $=0.000), 444.557(\mathrm{df}=6$, Sig. $=0.000), 75.822(\mathrm{df}=3$, Sig. $=0.000)$ and $166.145(\mathrm{df}=1$, Sig. $=0.000$ ), thus confirming there's sufficient relationship among variables to form factors. KMO sample suitability indicated $0.635,0.709,0.609$ and 0.500 each, and commonalities were over $0.554,0.712,0.481$, and 0.717 each, which meant it's possible to perform factor analysis.

\section{1) Lower dimension factors of plastic surgery perception}

Performing factor analysis produced three lower dimension factors as shown in Table 3, and 12 questions that didn't fit the meaning among other attributes were removed. Overall explanation power of lower dimension factors appeared as $77.4 \%$, and based on the questionnaire, 'lower dimension factor $1(31.3 \%)$ ' was named as 'positive', 'lower dimension factor 2(23.5\%)' was named 'reaction' and 'lower dimension factor 3(22.5\%)' was named 'improvement'

\section{2) Lower dimension factors of interest in appearance}

Performing factor analysis produced single lower dimension factor as shown in Table 4, and 6 questions that didn't match the meaning with other attributes of the variable were removed. Overall explanation power of the dimension was

Table 3. Plastic surgery perception factors analysis

\begin{tabular}{|c|c|c|c|c|}
\hline Measurement questions for cosmetic plastic surgery recognition. & Positive & Reaction & Improvement & Commonality \\
\hline $\begin{array}{l}\text { Cosmetic plastic surgery is one of the self-management methods to increase } \\
\text { competitiveness. }\end{array}$ & .836 & -.056 & .049 & .704 \\
\hline Cosmetic plastic surgery is an important factor in success. & .814 & .236 & .008 & .719 \\
\hline I think cosmetic surgery brightens people. & .814 & -.002 & .040 & .664 \\
\hline $\begin{array}{l}\text { If your opposite sex friend is undergoing cosmetic plastic surgery, I would highly } \\
\text { recommend it. }\end{array}$ & 657 & .270 & .224 & .554 \\
\hline I think I'll be satisfied with the results after undergoing cosmetic plastic surgery. & .037 & .947 & .088 & .907 \\
\hline $\begin{array}{l}\text { If I undergo cosmetic plastic surgery, I think people around me will respond } \\
\text { positively. }\end{array}$ & .184 & .923 & -.036 & .886 \\
\hline Cosmetic plastic surgery helps change appearance. & .117 & .005 & .935 & .889 \\
\hline Cosmetic plastic surgery can fill in body parts or shortcomings that you don't like. & .057 & .049 & .931 & .872 \\
\hline Unique value & 2.507 & 1.883 & 1.804 & \\
\hline Description variance $(\%)$ & 31.335 & 23.533 & 22.551 & \\
\hline Accumulated variance $(\%)$ & 31.335 & 54.868 & 77.419 & \\
\hline Reliability factor Cronbach's $\alpha$ & 0.804 & 0.879 & 0.870 & \\
\hline
\end{tabular}


Table 4. Interest in appearance factor analysis

\begin{tabular}{|c|c|c|}
\hline $\begin{array}{l}\text { Interest in appearance measurement } \\
\text { question }\end{array}$ & $\begin{array}{l}\text { Interest in } \\
\text { appearance }\end{array}$ & Commonality \\
\hline I tend to care about how I look to others. & .871 & .759 \\
\hline $\begin{array}{l}\text { I think image making that suits me is } \\
\text { important. }\end{array}$ & .830 & .688 \\
\hline $\begin{array}{l}\text { I tend to pay more attention to my } \\
\text { appearance when I have class. }\end{array}$ & .750 & .563 \\
\hline $\begin{array}{l}\text { I am happy with the time I spend taking } \\
\text { care of myself. }\end{array}$ & .712 & .507 \\
\hline Unique value. & 2.518 & \\
\hline Description variance (\%) & 62.939 & \\
\hline Accumulated variance $(\%)$ & 62.939 & \\
\hline Reliability factor Cronbach's $\alpha$ & 0.789 & \\
\hline
\end{tabular}

Table 5. Appearance orientation factor analysis

\begin{tabular}{lcc}
\hline $\begin{array}{l}\text { Measurement questions for appearance } \\
\text { orientation }\end{array}$ & $\begin{array}{c}\text { Appearance } \\
\text { orientation }\end{array}$ & Commonality \\
\hline I wish I could be prettier. & .778 & .605 \\
\hline I wish I were slimmer. & .705 & .497 \\
\hline $\begin{array}{l}\text { There are many parts of my appearance } \\
\text { that I want to change. }\end{array}$ & 6.93 & .481 \\
\hline Unique value. & 1.583 & \\
\hline Description variance (\%) & 52.774 & \\
\hline Accumulated variance (\%) & 52.774 & \\
\hline \multicolumn{1}{c}{ Reliability factor Cronbach's $\alpha$} & 0.540 & \\
\hline
\end{tabular}

$62.9 \%$ and based on questions consisting the variable, 'lower dimension factor $1(62.9 \%)$ ' was named 'interest in appearance'.

\section{3) Lower dimension factors of appearance orientation}

Performing factor analysis produced single low dimension factor as shown in Table 5, and 7 questions that didn't match meaning with other attributes of the variable were removed. Overall explanation power of lower dimension factor was $52.7 \%$, then based on questionnaire that make up the factor, 'low dimension factor 1' was named 'appearance orientation'.

\section{4) Lower dimension factors of self-esteem}

Performing factor analysis produced single factor as shown in Table 6, and 8 questions that didn't match meaning with other attributes in the variable were removed. Overall explanation power of the dimension was $71.7 \%$, and based on questions making up the variable, 'lower dimension factor 1(71.7\%)' was named 'self-esteem'.
Table 6. Factor analysis of self-esteem

\begin{tabular}{lcc}
\hline Self-esteem measurement question & Self-esteem & Commonality \\
\hline $\begin{array}{l}\text { I think I'm at least a valuable person to } \\
\text { the same extent as others. }\end{array}$ & .847 & .717 \\
\hline $\begin{array}{l}\text { I think I have a lot of good } \\
\text { characteristics. }\end{array}$ & .847 & .717 \\
\hline Unique value. & 1.434 & \\
\hline Description variance (\%) & 71.714 & \\
\hline Accumulated variance (\%) & 71.714 & \\
\hline \multicolumn{1}{c}{ Reliability factor Cronbach's $\alpha$} & 0.598 \\
\hline
\end{tabular}

\section{Effect of demographic characteristics on plastic surgery perception, interest in appearance, appearance orientation and self-esteem}

In order to determine the different effects of demographic characteristics on plastic surgery perception, interest in appearance, appearance orientation and self-esteem, t-test, ANOVA analysis as well as scheffe-test produced following results.

\section{1) Effect of demographic characteristics on plastic surgery perception}

Results of analysis are in Table 7, and women showed higher reaction and improvement than men. Ages over 40s showed higher improvement factor than people in their 10s, 20s, 30s and 50s. People with monthly income of less than 34 million won had higher positive factor while those with less than 1 million won had the lowest Observing the distribution outcome of effect of demographic characteristics on plastic surgery perception, as women have historically demonstrated continued interest in beauty and such pursuit of beauty by modern women living in appearance oriented society have led to increased investment of time and money in chasing the goal of clean skin and shapely bodies(Lee, 2015), it probably resulted in more women showing higher reaction and improvement factors than men. Also, since elderly women engage in plastic surgery to delay the aging of their skin while women in their 30 s are interested in appearance due to their need to participate in social activities and forming relationships with other people, it seems like women show increased interest in appearance and engage in plastic surgery to alleviate appearance of wrinkles and delay the signs of aging skin. 
Table 7. Effect of demographic characteristics on plastic surgery perception

\begin{tabular}{|c|c|c|c|c|c|}
\hline & Characteristics & $\begin{array}{c}\text { Plastic surgery } \\
\text { perception factors }\end{array}$ & M & S.D & $\mathrm{F}(\mathrm{t})$ \\
\hline \multirow{6}{*}{ Gender } & Men & \multirow{2}{*}{ Positive } & 0.06 & 0.98 & \multirow{2}{*}{0.816} \\
\hline & Women & & -0.03 & 1.01 & \\
\hline & Men & \multirow{2}{*}{ Reaction } & -0.05 & 1.09 & \multirow{2}{*}{$-0.696 * * *$} \\
\hline & Women & & 0.03 & 0.95 & \\
\hline & Men & \multirow{2}{*}{ Improvement } & -0.08 & 1.03 & \multirow{2}{*}{$-1.034 * * *$} \\
\hline & Women & & 0.04 & 0.99 & \\
\hline \multirow{15}{*}{ Age } & $10 \mathrm{~s}$ & \multirow{5}{*}{ Positive } & -0.07 & 1.05 & \multirow{5}{*}{1.420} \\
\hline & $20 \mathrm{~s}$ & & -0.06 & 0.97 & \\
\hline & $30 \mathrm{~s}$ & & 0.00 & 0.95 & \\
\hline & $40 \mathrm{~s}$ & & 0.58 & 0.67 & \\
\hline & Over 50s & & 0.29 & 1.16 & \\
\hline & $10 \mathrm{~s}$ & \multirow{5}{*}{ Reaction } & -0.23 & 1.17 & \multirow{5}{*}{0.771} \\
\hline & $20 \mathrm{~s}$ & & 0.04 & 0.97 & \\
\hline & $30 \mathrm{~s}$ & & -0.07 & 1.14 & \\
\hline & $40 \mathrm{~s}$ & & 0.29 & 0.42 & \\
\hline & Over 50s & & 0.06 & 0.79 & \\
\hline & $10 \mathrm{~s}$ & \multirow{5}{*}{ Improvement } & $-0.17 \mathrm{~B}$ & 1.12 & \multirow{5}{*}{$4.992 * *$} \\
\hline & $20 \mathrm{~s}$ & & $0.15 \mathrm{AB}$ & 0.86 & \\
\hline & $30 \mathrm{~s}$ & & $-0.21 \mathrm{~B}$ & 1.02 & \\
\hline & $40 \mathrm{~s}$ & & $1.00 \mathrm{~A}$ & 0.67 & \\
\hline & Over 50s & & $-0.42 \mathrm{~B}$ & 1.31 & \\
\hline \multirow{12}{*}{$\begin{array}{l}\text { Education } \\
\text { level }\end{array}$} & Below high school & \multirow{4}{*}{ Positive } & 0.00 & 1.08 & \multirow{4}{*}{0.546} \\
\hline & Associate degree enrolled/graduated & & 0.12 & 1.15 & \\
\hline & College enrolled/graduated & & -0.06 & 0.86 & \\
\hline & Above grad school & & 0.00 & 1.02 & \\
\hline & Below high school & \multirow{4}{*}{ Reaction } & -0.07 & 1.09 & \multirow{4}{*}{0.619} \\
\hline & Associate degree enrolled/graduated & & 0.02 & 1.02 & \\
\hline & College enrolled/graduated & & 0.06 & 0.91 & \\
\hline & Above grad school & & -0.20 & 1.18 & \\
\hline & Below high school & \multirow{4}{*}{ Improvement } & -0.12 & 1.04 & \multirow{4}{*}{1.442} \\
\hline & Associate degree enrolled/graduated & & -0.06 & 1.09 & \\
\hline & College enrolled/graduated & & 0.12 & 0.93 & \\
\hline & Above grad school & & -0.19 & 0.97 & \\
\hline \multirow{9}{*}{$\begin{array}{l}\text { Marriage } \\
\text { status }\end{array}$} & Single & \multirow{3}{*}{ Positive } & -0.04 & 0.98 & \multirow{3}{*}{1.625} \\
\hline & Married & & 0.18 & 1.09 & \\
\hline & Other (divorced, bereaved, separated, etc.) & & 0.58 & 0.91 & \\
\hline & Single & \multirow{3}{*}{ Reaction } & 0.00 & 1.03 & \\
\hline & Married & & -0.05 & 0.82 & 0.454 \\
\hline & Other (divorced, bereaved, separated, etc.) & & 0.45 & 0.86 & \\
\hline & Single & & 0.04 & 0.92 & \\
\hline & Married & Improvement & -0.25 & 1.35 & 1.642 \\
\hline & Other (divorced, bereaved, separated, etc.) & & 0.03 & 1.27 & \\
\hline
\end{tabular}


Table 7. Continued

\begin{tabular}{|c|c|c|c|c|c|}
\hline & Characteristics & $\begin{array}{c}\text { Plastic surgery } \\
\text { perception factors }\end{array}$ & M & S.D & $\mathrm{F}(\mathrm{t})$ \\
\hline \multirow{18}{*}{$\begin{array}{l}\text { Monthly } \\
\text { income }\end{array}$} & Less than 1 million won & \multirow{6}{*}{ Positive } & -0.23 & 0.91 & \multirow{6}{*}{$3.783 * *$} \\
\hline & Less than 1-2 million won & & -0.06 & 1.09 & \\
\hline & Less than 2-3 million won & & 0.12 & 1.05 & \\
\hline & Less than 3-4 million won & & 0.63 & 0.99 & \\
\hline & Less than 4-5 million won & & 0.39 & 0.52 & \\
\hline & More than 5 million won & & 0.19 & 0.91 & \\
\hline & Less than 1 million won & \multirow{6}{*}{ Reaction } & 0.07 & 0.87 & \multirow{6}{*}{0.463} \\
\hline & Less than 1-2 million won & & -0.11 & 1.15 & \\
\hline & Less than 2-3 million won & & -0.06 & 0.97 & \\
\hline & Less than 3-4 million won & & -0.10 & 1.20 & \\
\hline & Less than 4-5 million won & & 0.24 & 0.54 & \\
\hline & More than 5 million won & & 0.07 & 1.09 & \\
\hline & Less than 1 million won & \multirow{6}{*}{ Improvement } & 0.12 & 0.89 & \multirow{6}{*}{2.093} \\
\hline & Less than 1-2 million won & & -0.21 & 0.96 & \\
\hline & Less than 2-3 million won & & -0.08 & 1.11 & \\
\hline & Less than 3-4 million won & & 0.42 & 0.82 & \\
\hline & Less than 4-5 million won & & 0.26 & 1.18 & \\
\hline & More than 5 million won & & -0.14 & 1.16 & \\
\hline
\end{tabular}

${ }^{* *} p<0.01,{ }^{* * *} p<0.001$ Scheffé-test : A $>\mathrm{B}$

2) Effect of demographic characteristics on interest in appearance

Results of analysis are in Table 8, and women showed higher interest in appearance than men. Those with education level of college enrolled/graduated showed higher interest in appearance than those with associate degree enrolled/graduated and above grad school education levels. Those with monthly in come of less than 1 million won a month had highest interest in appearance while those with less than 3-4 million won monthly income had lowest interest in appearance. Observing the distribution outcome of effect of demographic characteristics on interest in appearance, it's probably that intense interest in appearance in society as a whole increases interest in beautiful appearance by the individuals seeking to enhance their external images. In research by $\operatorname{Kim}(2020)$, people in their 20s were most likely to start getting facial shape enhancing procedures and research by Lee(2005) showed most women showed interested in and started getting skincare procedures, thus partially supporting the data outcomes of this research.

3) Effect of demographic characteristics on appearance orientation
Results of analysis are in Table 9, and women showed higher appearance orientation than men. People in their 20s showed highest appearance orientation while those in their 30 s showed the lowest. For education level, those who were college enrolled/graduated showed highest appearance orientation while those with above grad school education level had the lowest outcome. For monthly income, those earning less than 1 million won showed highest appearance orientation while those earning less than 2-3 million won had the lowest outcome. Observing the distribution outcome of effect of demographic characteristics on appearance orientation is yet another example of the generally accepted knowledge that first impressions have bigger impact than personality or character when assessing others. In research by $\mathrm{Na}(2015)$, ages, marital status, number of children, average income and jobs demonstrated statistically significant differences and those in their 20s and 30s than higher appearance orientation tendency than those in their 40s and 50s, while unmarried people had higher appearance orientation than married people, thus partially supporting the results of this research.

\section{4) Effect of demographic characteristics on self-esteem}

Results of analysis are in Table 10, and women showed 
Table 8. Effects of demographic characteristics on interest in appearance

\begin{tabular}{|c|c|c|c|c|c|}
\hline & Characteristics & $\begin{array}{l}\text { Interest in appearance } \\
\text { factors }\end{array}$ & M & S.D & $\mathrm{F}(\mathrm{t})$ \\
\hline \multirow{2}{*}{ Gender } & Men & \multirow{2}{*}{$\begin{array}{l}\text { Interest in } \\
\text { appearance }\end{array}$} & -0.20 & 1.00 & \multirow{2}{*}{$-2.547 *$} \\
\hline & Women & & 0.10 & 0.99 & \\
\hline \multirow{5}{*}{ Age } & $10 \mathrm{~s}$ & \multirow{5}{*}{$\begin{array}{l}\text { Interest in } \\
\text { appearance }\end{array}$} & -0.03 & 1.06 & \multirow{5}{*}{2.118} \\
\hline & $20 \mathrm{~s}$ & & 0.11 & 0.95 & \\
\hline & $30 \mathrm{~s}$ & & -0.21 & 1.12 & \\
\hline & $40 \mathrm{~s}$ & & 0.36 & 1.04 & \\
\hline & Over $50 \mathrm{~s}$ & & -0.28 & 0.94 & \\
\hline \multirow{4}{*}{$\begin{array}{c}\text { Education } \\
\text { level }\end{array}$} & Below high school & \multirow{4}{*}{$\begin{array}{l}\text { Interest in } \\
\text { appearance }\end{array}$} & $0.06 \mathrm{AB}$ & 1.10 & \multirow{4}{*}{$8.458 *$} \\
\hline & Associate degree enrolled/graduated & & $-0.40 \mathrm{~B}$ & 0.86 & \\
\hline & College enrolled/graduated & & $0.24 \mathrm{~A}$ & 0.91 & \\
\hline & Above grad school & & $-0.31 \mathrm{~B}$ & 1.18 & \\
\hline \multirow{3}{*}{$\begin{array}{l}\text { Marriage } \\
\text { status }\end{array}$} & Single & \multirow{3}{*}{$\begin{array}{l}\text { Interest in } \\
\text { appearance }\end{array}$} & 0.04 & 1.01 & \multirow{3}{*}{1.384} \\
\hline & Married & & -0.19 & 0.94 & \\
\hline & Other (divorced, bereaved, separated, etc.) & & -0.41 & 0.50 & \\
\hline \multirow{6}{*}{$\begin{array}{l}\text { Monthly } \\
\text { income }\end{array}$} & Less than 1 million won & \multirow{6}{*}{$\begin{array}{l}\text { Interest in } \\
\text { appearance }\end{array}$} & 0.37 & 0.90 & \multirow{6}{*}{$7.639 * * *$} \\
\hline & Less than 1-2 million won & & -0.42 & 0.92 & \\
\hline & Less than 2-3 million won & & -0.10 & 0.99 & \\
\hline & Less than 3-4 million won & & -0.44 & 1.13 & \\
\hline & Less than 4-5 million won & & 0.09 & 1.43 & \\
\hline & More than 5 million won & & -0.04 & 0.93 & \\
\hline
\end{tabular}

${ }^{*} p<0.05,{ }^{* * *} p<0.001$ Scheffé-test : A $>\mathrm{B}$

higher self-esteem than men. People in 40s showed highest self-esteem while those in their 50s showed the lowest. For education level, people with above grad school education showed highest self-esteem while those with associate degree enrolled/graduated education showed lowest self-esteem. Those with monthly income of less than 4-5 million won showed highest self-esteem while those earning less than 3-4 million won had the lowest self-esteem. Observing the distribution outcome of effect of demographic characteristics on self-esteem indicates those with higher social status tend to have higher self-esteem and in research by Joo(2015), differences in self-efficacy based on ages showed statistically significant impacts on confidence, self-control efficacy and self-efficacy, with those in their 50s showing highest level of confidence while those in their 40s showing self-control efficacy and self-efficacy, thus partially supporting the results of this research.

\section{Effects of plastic surgery perception on appearance orientation}

Looking at multicollinearity of plastic surgery perception and appearance orientation prior to performing multiple regression analysis, VIF values were all under 10, making it reasonable to perform multiple regression analysis and the results are shown in $<$ Table $11>$.

First, orientation factor was approximately $9.8 \%$ explained by positive, reaction and improvement factors. Furthermore, higher preference for reaction and improvement factors increased appearance orientation factor by $0.239,0.183$ times each, thus indicating positive effect, while higher preference for positive factor decreased appearance orientation factor by -0.125 times, thus indicating a negative effect. Therefore, viewing plastic surgery as a competitive self-management method, essential element for success, having positive impact and being aware of positives about plastic surgery will probably decrease orientation while not having impact on satisfaction. Being satisfied after plastic surgery and recognizing positive reaction of other people, enhanced appearance and improved physical flaws will increase orientation factor while not having impact on satisfaction factor.

Han \& Park(2008)'s Study of Appearance Maintenance 
Table 9. Effect of demographic characteristics on appearance orientation

\begin{tabular}{|c|c|c|c|c|c|}
\hline \multicolumn{2}{|c|}{ Characteristics } & $\begin{array}{l}\text { Appearance } \\
\text { Orientation } \\
\text { Factors } \\
\end{array}$ & M & S.D & $\mathrm{F}(\mathrm{t})$ \\
\hline \multirow{2}{*}{ Gender } & Men & \multirow{2}{*}{$\begin{array}{l}\text { Appearance } \\
\text { Orientation }\end{array}$} & -0.37 & 0.86 & \multirow{2}{*}{$-5.179 * * *$} \\
\hline & Women & & 0.19 & 1.01 & \\
\hline \multirow{5}{*}{ Age } & $10 \mathrm{~s}$ & \multirow{5}{*}{$\begin{array}{l}\text { Appearance } \\
\text { Orientation }\end{array}$} & -0.13 & 0.95 & \multirow{5}{*}{$5.684 * * *$} \\
\hline & $20 \mathrm{~s}$ & & 0.20 & 1.07 & \\
\hline & $30 \mathrm{~s}$ & & -0.46 & 0.79 & \\
\hline & $40 \mathrm{~s}$ & & 0.14 & 0.79 & \\
\hline & Over 50s & & -0.25 & 0.68 & \\
\hline \multirow{4}{*}{$\begin{array}{c}\text { Education } \\
\text { level }\end{array}$} & $\begin{array}{l}\text { Below high } \\
\text { school }\end{array}$ & \multirow{4}{*}{$\begin{array}{l}\text { Appearance } \\
\text { Orientation }\end{array}$} & -0.11 & 0.94 & \multirow{4}{*}{$3.662 *$} \\
\hline & $\begin{array}{l}\text { Associate } \\
\text { degree } \\
\text { enrolled/ } \\
\text { graduated }\end{array}$ & & -0.19 & 0.73 & \\
\hline & $\begin{array}{l}\text { College } \\
\text { enrolled/ } \\
\text { graduated }\end{array}$ & & 0.20 & 1.12 & \\
\hline & $\begin{array}{c}\text { Above grad } \\
\text { school }\end{array}$ & & -0.24 & 0.96 & \\
\hline \multirow[b]{3}{*}{$\begin{array}{c}\text { Marriage } \\
\text { Status }\end{array}$} & Single & \multirow[b]{3}{*}{$\begin{array}{l}\text { Appearance } \\
\text { Orientation }\end{array}$} & 0.05 & 1.04 & \multirow[b]{3}{*}{2.076} \\
\hline & Married & & -0.27 & 0.70 & \\
\hline & $\begin{array}{c}\text { Other } \\
\text { (divorced, } \\
\text { bereaved, } \\
\text { separated, etc.) }\end{array}$ & & -0.15 & 0.51 & \\
\hline \multirow{6}{*}{$\begin{array}{l}\text { Monthly } \\
\text { Income }\end{array}$} & $\begin{array}{l}\text { Less than } 1 \\
\text { million won }\end{array}$ & \multirow{6}{*}{$\begin{array}{l}\text { Appearance } \\
\text { Orientation }\end{array}$} & 0.47 & 1.12 & \multirow{6}{*}{$10.866 * * *$} \\
\hline & $\begin{array}{l}\text { Less than } 1-2 \\
\text { million won }\end{array}$ & & -0.28 & 0.86 & \\
\hline & $\begin{array}{c}\text { Less than } 2-3 \\
\text { million won } \\
\end{array}$ & & -0.42 & 0.74 & \\
\hline & $\begin{array}{l}\text { Less than } 3-4 \\
\text { million won }\end{array}$ & & 0.07 & 0.55 & \\
\hline & $\begin{array}{c}\text { Less than } 4-5 \\
\text { million won }\end{array}$ & & -0.17 & 0.96 & \\
\hline & $\begin{array}{l}\text { More than } 5 \\
\text { million won }\end{array}$ & & -0.30 & 0.80 & \\
\hline
\end{tabular}

Behavior about Makeup and Plastic Surgery indicated that interest in plastic surgery had positive $(+)$ correlation with appearance maintenance behavior, and Yoo(2013)'s A Study of the Effect of Appearance Interests and Appearance Management Behavior on Aesthetic Plastic Surgery indicated high interest in plastic surgery and positive $(+)$ effects and Lee(2008)'s College women Students' Perception of Cosmetic Surgery research demonstrated younger college students who
Table 10. Effect of demographic characteristics on self-esteem

\begin{tabular}{|c|c|c|c|c|c|}
\hline \multicolumn{2}{|c|}{ Characteristics } & $\begin{array}{l}\text { Self-esteem } \\
\text { Factors }\end{array}$ & M & S.D & $\mathrm{F}(\mathrm{t})$ \\
\hline \multirow{2}{*}{ Gender } & Men & \multirow{2}{*}{ - Self-esteem - } & -0.22 & 0.90 & \multirow{2}{*}{$-3.013 * *$} \\
\hline & Women & & 0.11 & 1.03 & \\
\hline \multirow{5}{*}{ Age } & $10 \mathrm{~s}$ & \multirow{5}{*}{ Self-esteem } & $-0.04 \mathrm{AB}$ & 0.98 & \multirow{5}{*}{$3.278 *$} \\
\hline & $20 \mathrm{~s}$ & & $0.12 \mathrm{AB}$ & 1.04 & \\
\hline & $30 \mathrm{~s}$ & & $-0.19 \mathrm{AB}$ & 0.85 & \\
\hline & $40 \mathrm{~s}$ & & $0.73 \mathrm{~A}$ & 1.06 & \\
\hline & Over $50 \mathrm{~s}$ & & $-0.39 \mathrm{~B}$ & 0.84 & \\
\hline \multirow{5}{*}{$\begin{array}{l}\text { Education } \\
\text { Level }\end{array}$} & $\begin{array}{l}\text { Below high } \\
\text { school }\end{array}$ & \multirow{5}{*}{ - Self-esteem } & -0.06 & 0.89 & \multirow{5}{*}{$3.650 *$} \\
\hline & $\begin{array}{c}\text { Associate } \\
\text { degree enrolled/ } \\
\text { graduated }\end{array}$ & & -0.29 & 0.92 & \\
\hline & graduated & & & & \\
\hline & $\begin{array}{l}\text { College } \\
\text { enrolled/ } \\
\text { graduated }\end{array}$ & & 0.15 & 1.01 & \\
\hline & $\begin{array}{l}\text { Above grad } \\
\text { school }\end{array}$ & & 0.18 & 1.30 & \\
\hline \multirow[b]{3}{*}{$\begin{array}{c}\text { Marriage } \\
\text { Status }\end{array}$} & Single & \multirow[b]{3}{*}{ Self-esteem } & 0.04 & 1.02 & \multirow[b]{3}{*}{1.403} \\
\hline & Married & & -0.22 & 0.85 & \\
\hline & $\begin{array}{c}\text { Other } \\
\text { (divorced, } \\
\text { bereaved, } \\
\text { separated, etc.) }\end{array}$ & & -0.15 & 0.68 & \\
\hline \multirow{6}{*}{$\begin{array}{l}\text { Monthly } \\
\text { Income }\end{array}$} & $\begin{array}{l}\text { Less than } 1 \\
\text { million won }\end{array}$ & \multirow{6}{*}{ Self-esteem } & 0.41 & 1.08 & \multirow{6}{*}{$8.089 * * *$} \\
\hline & $\begin{array}{l}\text { Less than } 1-2 \\
\text { million won }\end{array}$ & & -0.30 & 0.96 & \\
\hline & $\begin{array}{l}\text { Less than 2-3 } \\
\text { million won }\end{array}$ & & -0.25 & 0.73 & \\
\hline & $\begin{array}{l}\text { Less than } 3-4 \\
\text { million won }\end{array}$ & & -0.44 & 1.13 & \\
\hline & $\begin{array}{l}\text { Less than } 4-5 \\
\text { million won }\end{array}$ & & 0.48 & 1.09 & \\
\hline & $\begin{array}{l}\text { More than } 5 \\
\text { million won }\end{array}$ & & -0.17 & 0.66 & \\
\hline
\end{tabular}

are main customers of plastic surgery tend to be actively interested in appearance, thus partially supporting this research.

Therefore, dissatisfaction with current state resulted in appearance orientation, and previous studies partially support the outcome of this research.

To summarize, review events for promoting plastic surgery review on plastic surgery applications and encouraging active plastic surgery review teams on social media can lead to increased appearance orientation. 
Table 11. Effects of plastic surgery perception on appearance orientation

\begin{tabular}{|c|c|c|c|c|c|c|c|}
\hline $\begin{array}{c}\text { Independent variable } \\
\text { (plastic surgery perception) }\end{array}$ & $\begin{array}{c}\text { Dependent variable } \\
\text { (appearance orientation) }\end{array}$ & B & $\beta$ & $\mathrm{t}$ & $\mathrm{R}^{2}$ & Revised $\mathrm{R}^{2}$ & $\mathrm{~F}$ \\
\hline (Constant) & \multirow{4}{*}{$\begin{array}{l}\text { Appearance } \\
\text { orientation }\end{array}$} & 2.500 & & .000 & \multirow{4}{*}{0.106} & \multirow{4}{*}{0.098} & \multirow{4}{*}{$12.503 * * *$} \\
\hline Positive & & -.125 & -.125 & $-2.354 *$ & & & \\
\hline Reaction & & .239 & .239 & $4.487 * * *$ & & & \\
\hline Improvement & & .183 & .183 & $3.440 * *$ & & & \\
\hline
\end{tabular}

\section{Effects of plastic surgery perception on self-esteem}

Looking at multicollinearity of plastic surgery perception and appearance orientation prior to performing multiple regression analysis, VIF values were all under 10, making it reasonable to perform multiple regression analysis and the results are shown in $<$ Table $12>$.

First, self-esteem factor was approximately $15.3 \%$ explained by positive and improvement factors. Furthermore, higher preference for positive factor decreased self-esteem factor by -0.349 times, thus having negative effect. Higher preference for improvement factor increased self-esteem factor by 0.192 times, thus having positive effect.

Therefore, plastic surgery perception has partial positive effect on self-esteem and recognizing plastic surgery as a method of self-improvement, success factor and positive factor as well as having positive suggestion intention will have negative effect on self-esteem. Then, recognizing satisfaction level after plastic surgery and other people's reaction has negative effect on self-esteem. However, recognizing plastic surgery as a catalyst for change and method of improvement for alleviating flaws will have positive effect on self-esteem.

Beak(2013)'s The Relations Between Body Image and Cosmetic Surgery Attitude: Focusing on the Mediating Effect of Narcissism and Self-esteem, and on the Moderating Effect of Gratitude research indicated current sociocultural attitude towards appearance had negative effect on teenager's body image and plastic surgery intentions, and Kim(2007)'s Effects of Aesthetic surgery on Body Image, Self-esteem and Satisfaction with Outcomes research, plastic surgery is considered a form of medical procedure which can be measured for its impact on quality of life for an individual and surgery had an overall negative(-) effect, while Lee(2002)'s A Study on aesthetic plastic surgery, self-esteem and body image of some women research acknowledged meaning of a person's appearance can vary depending on the time periods and cultures but concluded that it has positive $(+)$ effect on self-esteem, interpersonal relationships and patterns of behavior.

According to the analysis, plastic surgery perception has partial effect on self-esteem, which highlights sociocultural attitudes about appearance and benefits of plastic surgery on

Table 12. Effects of plastic surgery perception on self-esteem

\begin{tabular}{|c|c|c|c|c|c|c|c|}
\hline $\begin{array}{c}\text { Independent variable } \\
\text { (plastic surgery perception) }\end{array}$ & $\begin{array}{l}\text { Dependent variable } \\
\text { (self-esteem) }\end{array}$ & B & $\beta$ & $\mathrm{t}$ & $\mathrm{R}^{2}$ & $\begin{array}{c}\text { Revised } \\
\mathrm{R}^{2}\end{array}$ & $\mathrm{~F}$ \\
\hline (Constant) & \multirow{4}{*}{ Self-esteem } & 3.341 & & .000 & \multirow{4}{*}{0.161} & \multirow{4}{*}{0.153} & \multirow{4}{*}{$20.077 * * *$} \\
\hline Positive & & -.349 & -.349 & $-6.766 * * *$ & & & \\
\hline Reaction & & -.042 & -.042 & -.813 & & & \\
\hline Improvement & & .192 & .192 & $3.714 * * *$ & & & \\
\hline
\end{tabular}

Table 13. Effects of interest in appearance on appearance orientation

\begin{tabular}{|c|c|c|c|c|c|c|c|}
\hline $\begin{array}{l}\text { Independent variable } \\
\text { (interest in appearance) }\end{array}$ & $\begin{array}{c}\text { Dependent variable } \\
\text { (appearance orientation) }\end{array}$ & B & $\beta$ & $\mathrm{t}$ & $\mathrm{R}^{2}$ & $\begin{array}{c}\text { Revised } \\
\mathrm{R}^{2}\end{array}$ & $\mathrm{~F}$ \\
\hline (Constant) & \multirow{2}{*}{$\begin{array}{l}\text { Appearance } \\
\text { orientation }\end{array}$} & 2.515 & & .000 & \multirow{2}{*}{0.049} & \multirow{2}{*}{0.046} & \multirow{2}{*}{$16.327 * * *$} \\
\hline Interest in appearance & & .221 & .221 & $4.041 * * *$ & & & \\
\hline
\end{tabular}


self image, self-esteem, satisfaction and one's quality of life, thus indicating partial support between previous studies and this research.

To summarize, increasing plastic surgery satisfaction through 3D virtual plastic surgery system and after-service happy calls can lead to increased self-esteem.

\section{Effects of interest in appearance on appearance orientation}

Looking at multicollinearity of plastic surgery perception and appearance orientation prior to performing multiple regression analysis, VIF values were all under 10, making it reasonable to perform multiple regression analysis and the results are shown in $<$ Table 13>.

First, appearance orientation factor was approximately $4.6 \%$ explained by interest in appearance factor. Furthermore, higher preference for interest in appearance factor increased appearance orientation factor by 0.221 times, thus having positive effect.

According to the outcomes, interest in appearance factor has negative effect on appearance orientation, and recognizing one's interest about other's views about appearance, imagemaking, appearance maintenance and development has negative effect on appearance orientation as well as satisfaction.

Lee(2021)'s The Effect of Self-respect and Satisfaction on Career Stress and Career Satisfaction in University Student Preparing for Employment research stated perception of one's own body and satisfaction with one's appearance can be largely negatively influenced by cultural standards of the times, and Yoo(2013)'s A Study of the Effect of Appearance Interests and Appearance Management Behavior on Aesthetic Plastic Surgery research indicated degree of interest in appearance and maintenance behavior can have negative effect on proper awareness of plastic surgery and interest in appearance.

According to the analysis outcomes, interest in appearance is influenced by perception of one's own appearance, satisfaction with appearance and proper awareness of plastic surgery through appearance orientation, thus supporting previous studies as well as this research.

To summarize, interest in appearance can be increased through appearance orientations such as participating in body photo shoots and beauty pageants.

\section{Effects of interest in appearance on self-esteem}

Looking at multicollinearity of plastic surgery perception and appearance orientation prior to performing multiple regression analysis, VIF values were all under 10, making it reasonable to perform multiple regression analysis and the results are shown in $\langle$ Table 14>.

Self-esteem factor can be explained by interest in appearance factor approximately $8.1 \%$, and higher inclination for interest in appearance factor increases self-esteem factor by 0.290 times, thus having positive effect.

Therefore, interest in appearance factor has positive effect on self-esteem and awareness of others' perceptions, imagemaking, appearance maintenance and interest in appearance factor have positive effect on self-esteem.

Jung(2018)'s The Effect of SNS Usage of Female College Students on Beauty Interest and Self-Esteem-Focused on Gwangju Metropolitan City Area research showed that when using social network sites for beauty information, less sharing and more consistency and utility increased self-esteem, thus having positive effect, Lee(2013)'s A Study on the Body Image and Sense of Psychological Stability Related to the Outward Appearance Management research showed that teenagers who are high in beauty interest and therefore highly interest in taking care of their looks demonstrated positive $(+)$ effect of beauty interest on appearance satisfaction and selfesteem.

According to the research outcome, higher interest in appearance meant longer time invested in taking care of oneself, which leads to higher self-esteem, thus partially supporting outcomes of previous studies and this research.

Table 14. Effects of interest in appearance on self-esteem

\begin{tabular}{|c|c|c|c|c|c|c|c|}
\hline $\begin{array}{l}\text { Independent variable } \\
\text { (interest in appeaarance) }\end{array}$ & $\begin{array}{l}\text { Dependent variable } \\
\text { (self-esteem) }\end{array}$ & B & $\beta$ & $\mathrm{t}$ & $\mathrm{R}^{2}$ & $\begin{array}{c}\text { Revised } \\
\mathrm{R}^{2}\end{array}$ & $\mathrm{~F}$ \\
\hline (Constant) & \multirow{2}{*}{ Self-esteem } & 1.003 & & .000 & \multirow{2}{*}{0.084} & \multirow{2}{*}{0.081} & \multirow{2}{*}{$29.072 * * *$} \\
\hline Interest in appearance & & .290 & .290 & $5.392 * * *$ & & & \\
\hline
\end{tabular}


To summarize, in order to increase interest in appearance, participating in self-makeup classes to increase self-esteem can increase overall interest in appearance which can result in general higher levels of self-esteem.

\section{Conclusion}

Purpose of this research is to determine the effects of plastic surgery perception and interest in appearance on appearance orientation and self-esteem in order to find ways to encourage appearance orientation and increase self-esteem, and results are the following.

First, positive factor of plastic surgery perception variable has negative(-) effect on appearance orientation factor of appearance orientation variable, and reaction and improvement factors of plastic surgery perception variable have positive $(+)$ effect on appearance orientation factor of appearance orientation variable. Also, positive factor has negative(-) effect on selfesteem, and improvement factor of plastic surgery perception variable has positive $(+)$ effect on self-esteem. Second, interest in appearance has positive $(+)$ effect on orientation factor of appearance orientation variable. Also, interest in appearance has positive $(+)$ effect on self-esteem. Suggested solutions based on these findings are the following.

First, those who considered plastic surgery as important in self-management, success and happiness had rather less desire to work on improving their appearance and less appearance orientation, and it's probably that these people already had high enough self-esteem to admit the importance of plastic surgery while not feeling the need for plastic surgery themselves.

Awareness of successful plastic surgery outcomes and improvements have positive effect on orientation factor of appearance orientation variable and self-esteem. Hence, providing happy-call services that check up on people after they get plastic surgery and providing virtual 3D plastic surgery can help improve plastic surgery perception, which can then positively influence appearance orientation and selfesteem.

Second, those who wished to impress others by imagemaking had greater desire to become more beautiful and slender. Therefore, utilizing body-positive photo shoots and beauty pageants as motivation for continued interest in exercise can help people become more appearance oriented in positive ways. Also, those who focus on image-making tend to consistently take care of themselves and reported higher satisfaction with their current body proportions and weight, and viewed themselves as highly worthy people Therefore, participating in activities like self-makeup courses can increase confidence in taking care of one's appearance, which can then increase one's self-esteem.

For future research, since there is continued interest in plastic surgery perception and purposeful approach to plastic surgery as well as variety of events and programs that draw attention from people that can positively impact appearance orientations and self esteem, it'll be meaningful research to connect behavior characteristics to psychological characteristics to discover influential relationships among those variables.

\section{References}

Beak, I. H. (2013). The Relations Between Body Image and Cosmetic Surgery Attitude: Focusing on the Mediating Effect of Narcissism and Self-esteem, and on the Moderating Effect of Gratitude. Master's thesis, Ewha Womans University Graduate school. pp. 1-117.

Boo, E. J. (2012). Analysis of the Structural Relationship among Career Goals, Career-related Goal Engagement, and the School Adjustment of Rural High School. Master's thesis, Seoul University Graduate school. pp. 8-55.

Choi, S. K. (2016). The effect of state of makeup and makeup behavior factors on self-esteem and interpersonal relationship among middle and high school girls. Master's thesis, Sookmyung University Graduate school. pp.1-85.

Chung, J. Y. (2003). The Body Management Behaviors and Clothing Benefits Sought according to Body Cathexis and Appearance Interest of High School Students. Master's thesis, Dongguk University Graduate school, pp. 3-16.

Han, D. J., \& Park, K. S. (2008).The Effect of Basic Occupational Competence Perceived by College Students Majoring in Beauty Major on Career Decision-Making Self-Efficacy and Major Continue Intention. Journal of the Korean Society of Cosmetology, 27(4), 903-910.

Huh, E. S. (2011). Characteristics of Recognition of Cosmetic Surgery on a University Hospital Nurses. Master's thesis, Wonkwang University Graduate school. pp. 1-48.

Hong, S. N. (2013). Appearance Management Behavior According to Interest in Appearance and Body Satisfaction of Korean Women and Migrant Women. Doctoral dissertation, Konkuk University Graduate school. pp. 1-121.

Hwang, H. A. (2007). Effect Factor in Cosmetic Surgery and Skin Care Experience of College Student. Master's thesis, Daegu Haany University Graduate school. pp. 1-45.

Joo, H. N. (2015). The Affect of Demographic Variables and Behavior of Purchasing Cosmetic products on Self-Esteem and SelfEfficacy. pp. 1-93. 
Jeong, J. K. (2009). Influential factors for Women workers' recognition of Cosmetic Surgery. Master's thesis, Kosin University Graduate school, pp. 1-38.

Jung, E. M. (2018). The Effect of SNS Usage of Female College Students on Beauty Interest and Self-Esteem -Focused on Gwangju Metropolitan City Area?. Master's thesis, Kwangju Women's University Graduate school. pp. 1-67.

Kim, S. H. (2009). A Study of Women's Make-up Behavior and Cosmetic Plastic Surgery Behavior According to Age Group. Doctoral dissertation, Dongseo University Graduate school. pp. 1150.

Kim, H. S. (2011). A study on the awareness and interest about appearance of cosmetic surgery of adults. Master's thesis, Seokyeong University Graduate school. pp. 1-141.

Kaiser, S. B. (1990). The social psychology of clothing. Symbolic appearances in context, 2. New York: Macmillan.

Kim, H. J. (2008). A Study on the Appearance Involvement and Clothing Consumption Value depending on Narcissism. Doctoral dissertation, Ewha womans University Graduate school. pp. $1-159$.

Kim, K. M. (2009). Attributes of Purchsasing Herbal Cosmetics According to Women's interest rates of appearances, Journal of the Korean Society of Cosmetology, 11(3), 265-271.

Kim, M. S. (2017). Effects of Team Cohesiveness, Team Goal-Setting and Perception of Co-Worker Task Ability on Team Performance. Master's thesis, Daegu University Graduate school. pp. $1-40$.

Kim, R. B. (2020). Interest in Appearance and Face Contouring Perception \& Behavior and their Effects on Psychological Utility. pp. $1-115$.

Kim, T. H. (2014). A Study of Consumer Behavior for Nail Care by Appearance Interest. Doctoral dissertation, Kyungsung University Graduate school. pp. 1-102.

Kim, Y. J. (2007). Effects of Aesthetic surgery on Body Image, Selfesteem and Satisfaction with Outcomes. Journal of the Korean Society of Cosmetology, 13(3), 1236-1246.

Lee, D. H. (2008). College women Students' Perception of Cosmetic Surgery. Master's thesis, Kosin University Graduate school. pp. $1-41$.

Lee, K. M. (2020). The Effect of Self-respect and Satisfaction on Career Stress and Career Satisfaction in University Student. Preparing for Employment. Doctoral dissertation, Sejong Univer- sity Graduate school, pp. 1-113,

Lee, J. H. (2018). Cosmetic Plastic Surgery Behavior According to Interest in Appearance and Perception on Plastic Surg. Master's thesis, Honam University Graduate school. pp. 1-74,

Lee, J. M (2015). A Study on the State of Women's Cosmetic Surgery and Satisfaction Level. Master's thesis, Sookmyung Women's University. pp. 1-77,

Lee, J. M., \& Jang, H. S. (2013). A Study on the Body Image and Sense of Psychological Stability Related to the Outward Appearance Management. Journal of the Korean Society of Cosmetology, 19(6), 1174-1185,

Lee, K. S. (2002). A Study on aesthetic plastic surgery, self-esteem and body image of some women. Master's thesis, Chosun University Graduate school. pp. 1-41.

Lee, S. L. (2005). Relationship between sexual consciousness, selfesteem, and stress coping methods of college students in Seoul: Focusing on college students in Seoul. Master's thesis, Chongshin University Graduate school. pp. 1-88.

Lim, S. E., Kweon, S. A., \& Choi, J. M. (2018). Effect of Appearance Awareness and Attitude toward Appearance on Appearance Management Behavior of University Students in Chungbuk. Journal of the Korean Society of Cosmetology, 24(5), 925-937.

L, Y. S. (2005). The Customer's The Customer's Customer's Preference Preference Preference for the Service at Service at the Skin Care Shop. pp. 1-93.

$\mathrm{Na}, \mathrm{H}$. J. (2015). A study on the appearance management behavior of adult male. pp. 1-124.

Oh, B. Y. (2010). Using Prediction Markets in Goal Setting: The Impact on Performance Prediction Accuracy and Task Performance. Doctoral dissertation, Hongik University Graduate school. pp. 1-119.

Yoo, H. S. (2013). A Study of the Effect of Appearance Interests and Appeance Management Behavior on Aesthetic Plastic Surgery. Master's thesis, Chodang University Graduate school. pp. 1-41.

Yoon, S. Y. (2007). A Study on Cognition and Attitude toward Appearance Management in College Women: Focused on Hair, Skin Care, Makeup, and Cosmetic Surgery. Master's thesis, Hannam University Graduate school. pp. 1-103.

Yu, H. S. (2013). A Study of the Effect of Appearance Interests and Appearance Management Behavior on Aesthetic Plastic Surgery. Master's thesis, Chodang University Graduate school. pp. $1-52$. 